\title{
Policing in an Era of Uncertainty
}

\author{
By \\ Janet Ransley \\ and \\ Lorraine Mazerolle
}

Griffith University

Australia

March 2008

Revised May 2008 


\begin{abstract}
The $21^{\text {st }}$ century has brought new challenges for police, in Australia as in other western democracies. Terrorism, globalisation, large-scale population movements and entrenched social problems pose crime control threats that are increasingly seen as beyond the scope and capabilities of traditional policing. New agencies have been established, private policing has boomed, and governments have sought to make individuals, businesses and community organisations increasingly responsible for their own safety. To maintain, or regain, their leadership of this new agenda, police agencies need first to recognise and understand the changing environment and its challenges. Our paper uses the theory and policy framework of "third party policing" to examine the role of police in this age of insecurity, complexity and uncertainty.
\end{abstract}




\section{Introduction}

Australian police face new challenges in the $21^{\text {st }}$ century. Like other western nations, Australia's new crime problems include preventing terrorism both domestically and in neighbouring countries; controlling the arrival of people displaced by violence, poverty and climate change; peace-keeping in failing states; and responding to new economic and technological crimes. Police are also increasingly involved in addressing social problems such as responding to entrenched disadvantage in Indigenous communities, people with mental illnesses, and a perceived growth in anti-social behaviour. These new challenges have arisen against the background of ongoing ‘old’ crime problems of drugs, property crime and violence.

In this changing cultural and social climate, contemporary policing is marked by the diversification and uncertainty of crime control problems. Prior models of policing could focus on relatively known and stable categories of offences and offenders, and on traditional, reactive responses to them. The new problems evolve rapidly, depend on a broad range of political, social, technological and economic factors, and require new skills and innovative and flexible responses. Existing models of policing generally do not have these attributes.

Police are challenged not just by the new paradigm, but also by their declining relevance and effectiveness as the central agents of crime control. Until recently, public police dominated the delivery of modern crime control. But trends in governance and the regulation of society have led to the pluralisation and privatisation of policing efforts, and the growth in administrative and regulatory agencies with crime control and prevention functions (Ericson, 2007). Additionally, a trend to responsibilisation has meant that communities and individuals are expected to contribute to their own regulation, security and safety (Crawford, 2006b). Contemporary policing services are increasingly provided by networks of public, private and welfare organisations, with public police as one node of the network.

Despite the early promise of community, problem-oriented and other innovative models of policing (Weisburd \& Braga, 2006), police are increasingly displaced or subjugated by these other agents and nodes of crime control. A growing literature describes how functions once largely monopolised by public police are now shared among different security providers, such as state and private security services; military, regulatory and welfare agencies; transnational organisations; and private interests (see Bayley \& Shearing, 1996, 2001; Loader, 2006; 
Crawford, 2006a, 2006b; Wood, 2006; Mazerolle \& Ransley 2005, 2006). This trend has led to the need for a redefinition of the policing function, as well as a redefinition of the role that the public police occupy within these new structures (Shearing, 2006).

Our paper explores the role and function of police in this current "era of uncertainty.” We argue that despite the rise of other crime control agents, public police are best placed to lead responses to existing and new crime problems, using new approaches based on intelligence, analysis and the active coordination of other nodes. But for them to do that effectively, police need a new model that guides their main functions and activities in the new era. We suggest “third party policing” as an appropriate model. We begin our paper with an examination of the new challenges of policing in this era of uncertainty. We then use Kelling and Moore's (1988) models of policing to explicate the elements that both define and distinguish policing in this post 9/11 environment. We highlight the risks faced by public police if, or when, leadership of the police agenda is relinquished to a more complex, nodal form of crime and terrorism control.

\section{New challenges}

\section{Policing terrorism}

The terrorist attacks of 9/11 in the United States and subsequently in Bali, Madrid and London, marked the arrival of new forms of attack on the security and safety of nations where previously terrorism had been virtually unknown (such as Australia) or relatively sporadic and localised (Britain and the United States). Groups such as al-Qaeda and Jemaah Islamiyah have been prepared, as Innes (2006) puts it, to engage in symbolic crimes, directed at iconic social or cultural targets (eg the Pentagon), signal crimes (eg transport and nightclub bombings), intended to disrupt everyday life and perceptions of security, and spectacular crimes that combine the two types (eg the World Trade Centre).

The scale of these threats, their repeated occurrence in various unpredictable locations, and the apparent inability of security and police organisations to prevent them, marked a new and urgent imperative for governments. The common domestic response among western nations, in addition to the military responses in Afghanistan and Iraq, was new legislation, agencies, powers, and surveillance techniques for security services, police, the military and a variety of other state and non-state agencies. In Australia, for example, successive new legislation from 2001 onwards has greatly expanded the size, role and functions of the Australian Federal 
Police (AFP - a national agency), given them broad new powers, and expanded and harmonised the counter-terrorist functions of the various state and territory police (responsible for most criminal law enforcement). All public police agencies in Australia now have counterterrorism branches, and participate in the National Counter-Terrorism Committee and its planning processes. The AFP has an operations centre in Indonesia, working closely with, and helping train, local counter-terror forces (McFarlane, 2007) New policing powers of detention and questioning have also been given to the main domestic security agency, the Australian Secret Intelligence Organisation (ASIO) and on occasions to the military, and policing functions and powers have been very broadly extended to local governments, port and airport authorities, infrastructure providers and providers of financial and private security services (see Baldino, 2007; Goldsmith, 2008; Palmer \& Whelan, 2006). Although there is little research evidence yet available about the outcomes of these efforts, the structural changes that have been made are clear - the policing of terrorism has become more empowered, focused on prevention and emergency response, but also more diffuse, with responsibilities shared among many different public and private agencies. The central coordination role is performed not by police, but by a secretariat in the federal government bureaucracy (Australia, 2005). Successive reviews have found that cooperation and coordination between police and different agencies is a continuing problem (e.g. Street, 2008) with police interests sometimes subjugated to other functional and bureaucratic agendas.

\section{Other emerging security issues}

While the policing of terrorism has been the focus of much attention, other new issues are emerging that also challenge existing police practices. Australia has been an active participant in providing police as peace-keepers and trainers in the development of democratic policing in former war-zones or failing states. This role recognises the need for participation in international efforts to strengthen policing in places where terrorism develops, such as Iraq and Indonesia, and to prevent the problems that might be caused by the collapse of failing states in the region, such as East Timor and the Solomon Islands (Bayley, 2005, 2006). The collapse of such nations could lead to human rights abuses, provide haven for terrorists, and lead to mass refugee movements. Participation in these missions has exacerbated organisational problems, such as staff shortages and deficiencies in training, but has also required police to adopt new or different roles. International deployments focus on the maintenance of security, community and capacity building, and the development of democratic practices (Bayley, 2005, 2006). Police have participated in these activities as part 
of task-forces or teams, alongside international, military, public sector, aid and welfare agencies. The skills required for these tasks are significantly different to those required in policing mainstream crimes domestically, with McFarlane (2007) emphasising the need for deployed police to have both an understanding of regional historical, cultural and language issues, and the role of community policing in developing and strengthening democratic institutions.

Another emerging problem has centred on increases in movements of people, as refugees from political unrest, poverty and potentially from climate change. While Australia has always had to deal with unauthorised arrivals (Crock, Saul \& Dastyari, 2006), the problem has recently developed new dimensions. Since 2001, refugees from countries such as Iraq and Afghanistan have raised potential national security concerns (Nicholls, 2007). Additionally, the experience of epidemics such as AIDS, SARS and bird flu has led to fears of epidemicaffected populations arriving. As a result, new immigration controls have been developed or strengthened and there is considerable overlap between these controls and those directed at restricting terrorism and other crime threats, bringing police and other agencies such as those responsible for immigration, customs and public health into closer working proximity. On occasions, those overlapping roles have been poorly coordinated and deficient (see Street, 2008; Palmer, 2005).

Also, Australian police are increasingly being called upon to play a greater role in responding to entrenched social problems, and anti-social behaviour. This role responds to threats to social cohesion and security challenges from within, as opposed to the external threats discussed above. For example, Indigenous communities, often located in extremely remote areas and lacking in virtually all forms of social service and infrastructure, have long been marked by extreme social dysfunction (lack of employment, poor housing and education, very high rates of alcohol and drug abuse) and very high rates of violent and sexual victimisation of women, children and babies. Until recently such communities suffered from benign neglect and under-policing, often in an attempt not to worsen already high rates of over-representation of Indigenous men in the criminal justice system. A radical new federal government policy in 2007 required a proactive police and military response in communities in the Northern Territory. As part of the response, police and military officers are required to facilitate health checks of children, prevent alcohol consumption, encourage school attendance, build infrastructure and engage in other forms of socialising behaviours that far exceed traditional 
police roles (Howard-Wagner, 2007). While no research has yet been published on the implementation or effectiveness of these measures, it is clear that the police involved face significant new challenges. These challenges are also experienced in dealing with other forms of internal threat, such as those posed by police interactions with mentally ill people, and antisocial behaviour caused by excessive public consumption of alcohol. In all of these situations, the police role is extending beyond traditional crime threats to focus on entrenched social problems, but this is a role that is shared with other public and private agents, and in which the police are not necessarily the central agency.

\section{Diversity and uncertainty}

There are some common elements to the new and emerging security problems described in the previous section. First, terrorism, international deployments, movements of people, and entrenched social problems all involve crime and security threats outside the traditional policing paradigm focused on street crimes. Second, none of these problems can be resolved by traditional reactive means, but instead require approaches blending intelligence collection, analysis, new technology and techniques, teams and problem-solving. Third, in each there has been a blurring of boundaries between criminal and social or political problems, and between responses from security or military and police services, or public and private agencies. And finally, for each example identified, the nature, boundaries and sometimes even the existence of the problem itself, was and continues to be uncertain and fluid.

Indeed, uncertainty is the hallmark of the new era of policing, along with the diversity of problems encompassed. A growing body of scholarly work considers the problem of uncertainty. Bammer and Smithson (2008) describe uncertainty as a fact of life, a pervasive force affecting and shaping all kinds of decision-making. In disciplines such as economics, statistics, and the physical and environmental sciences, considerable attention has been paid to understanding the boundaries and impact of uncertainty (see Dequech, 2004; Smithson, 1993; Norton, Brown and Mysiak, 2006; Bammer, 2007). In these sciences, aspects of uncertainty are measured, simulated and modelled, as an aid to decision-making.

An integrated analysis (Bammer, Smithson \& Goolabri, 2008) uses three categories of uncertainty. First there are known unknowns, where there is some knowledge of a problem, but its extent and boundaries are unclear. Second, there are unknown knowns, where tacit knowledge about a problem or practice exists but has not been adequately recorded or 
described. Third, there is meta-ignorance, where there are problems not yet known at all, including the very existence of the problem. Decision-making in this last area tends to be typified by high levels of ignorance, a predominance of subjective judgements substituting for actual experience, and a basis of ethical or moral grounds as much as risk assessments (Bammer, 2007). The onset of HIV/AIDS can be seen as an example (Bammer, Smithson \& Goolabri, 2008) where until its appearance, there was a belief that communicable diseases were being brought under control, no knowledge of the existence of the virus or of the capacity for virulent new viruses to develop, and no knowledge of how to respond. As the problem emerged, scientific decision-making was accompanied or displaced by an emphasis on moral aspects of the illness (eg individual choices in engaging in risky sex or drug-taking behaviours) (Bowtell, 2007). This was extreme meta-uncertainty. The spread of SARS by comparison, can be seen as a known unknown - the virus itself was unknown, but HIV/AIDS had demonstrated that new viruses could develop, and lessons in responding had already been learned which were likely to have some use in facing the new threat. These lessons covered not just scientific understanding, but social, political and economic factors in developing workable responses. Clearly this type of unknown is more easily managed than metaignorance, and in disciplines where uncertainty has been studied, much of the focus has been on reducing meta-ignorance or deep uncertainty, and developing guides to dealing with more predictable unknowns, although with the acknowledgement that some forms of uncertainty can never be known.

There are other taxonomies describing uncertainty. Smithson $(1989,1993)$ has divided ignorance into error and irrelevance, where error is distorted or incomplete knowledge, and irrelevance involves ignoring knowledge, because of taboos, untopicality or undecidability. The decision to ignore knowledge on these bases may be influenced by political, social or moral factors. Using HIV/AIDS as an example again, incomplete scientific and public health knowledge about the disease can be seen as accompanied by taboos (eg about acknowledging or condoning homosexuality and drug-using), and untopicality, where changing sexual and drug-using behaviours was not necessarily seen as a legitimate function of government health agencies (Bowtell, 2007).

These concepts about uncertainty have relevance for security threats like that posed by terrorism. This is first because the promotion of uncertainty is seen as a goal in itself of terrorist activity, both because it can lead to fear and disruption (Gill, 2001; McFadden, Lyon 
and Pinsker, 2008), and because the very act of terrorist violence communicates a political message, that violence can be used to achieve a desired outcome (Innes, 2006). So responding to and minimising the uncertainties of terrorism forces a way of dealing with the problem.

Second, uncertainty is important to terrorism because it creates an imperative for governments to be seen to be doing something to respond to the problem. The new 'public safety' agenda (Weisburd and Braga, 2006) for police involves the need for public reassurance that traditional policing demands continue to be met, while a new set of counter-terrorism demands is also managed. Third, there is clearly scope for subjectively-based moral assessments and taboos to influence the response to terrorism. So, some critics of counterterrorism measures have suggested they are based on an active distrust of foreigners, governments and other citizens, with whole populations and states being seen as potential terrorists (Beck, 2002), without any evidentiary basis for this assessment. The new uncertain environment shifts the focus from responding to crime, to 'a new mood of prevention, preemption and precaution' (Goldsmith, 2008, 145; Dershowitz, 2005). Rather than being accused of doing nothing to prevent unknown risks, governments replace evidence of risk with suspicion and worst-case scenarios (Goldsmith, 2008; Stern \& Wiener, 2006), and legislate accordingly.

Smithson (2008) suggests four adaptive challenges in facing uncertainty. First, there is a need to deal with unforseen threats and solve problems in situations that cannot wait for certainty to be reached. The second challenge asks how to use uncertainty as a platform for exploration and discovery. The third challenge is to build good outcomes in a world that is only partly knowable, and the fourth is how this can be done in an evidence-based and socially acceptable way. For the contemporary policing environment, these adaptive challenges focus on how uncertainty about new threats can be reduced, or at list shifted from meta-ignorance to a lesser form of uncertainty. For example, police need to develop knowledge and understanding about the nature, extent and tactics of current and unknown threats. To date, most efforts at this have focused on using traditional intelligence models. The limitation of this response is that it is by nature reactive - it responds to threats that have already become visible, either through an achieved or failed attack. How can intelligence be gathered about threats not yet known, the HIV/AIDS of terrorism or climate change? 


\section{A new era of policing?}

There are two dimensions to the argument that policing has now shifted into an era of uncertainty (see Gill, 2006). The first is descriptive, discussing the contours of the new environment, the threats posed and responses to them. We have described this new environment in the previous section. The second theme is normative, asking whether and how the new form of policing can be conceived and implemented in a way that reduces rather than increases fear and uncertainty, and maintains the core principles of democratic policing in the face of new internal and external security threats.

Some writers have characterised this theme as a merging of the boundary between 'high' and 'low' policing, where the first is focused on protecting the interests of the state, and the second on individual citizens (see Brodeur, 2007; Bayley \& Weisburd, forthcoming; Clarke and Newman, 2007; Innes, 2006; Crawford, 2006a). High policing was traditionally the function of security services using covert intelligence gathering directed at circumventing threats, while low policing was performed by public police, based on overt strategies of disruption of crime opportunities (Brodeur, 2007). In this division, intelligence was mainly directed at external threats, foreigners and disloyal insiders seeking to destabilise the state. The policing function of the state was directed at the mainstream population, and needed more care to distinguish between ordinary citizens and offenders, and the fluidity with which individuals could move between the two categories. Hence, the state constrained the role and function of policing to develop civil rights and legal protections for its targets that were not needed in dealing with outside threats to the state. In this model, traditional policing is based on reasonableness (Kennison \& Loumansky, 2007) and proportionate responses to offences.

In the post 9/11 environment, terrorism and other new threats are seen as both threats to the state and to individual citizens. As such, responses have developed that blur the old boundaries. Police have been given 'high' powers, for example, of detention and surveillance in the absence of criminal charges or convictions. Security services have been given 'low' powers, for example to detain and interrogate suspects, and to patrol and exclude citizens from sites seen as targets (eg sporting or political events). Ericson (2007) argues that this trend to enabling provisions in counter-terrorism laws has narrowed the differences between high and low policing. 
The available evidence does not altogether support this argument. Bayley and Weisburd (forthcoming) surveyed models of counter-terrorist policing in modern democratic states and found several different variations, largely linked to the political structures and policing histories of the states (eg whether they were federations or unitary states). They found states where counter terrorism was performed by a specialised national agency; a national police service with a counter-terror unit; all police agencies whether national, regional or local; or a mix of some or all of these units. There was no one dominant model, where high and low policing had merged. Another study of United States police agencies (Ortiz, Hendrichs \& Sugue, 2007) found that while there had been distinct political and economic pressures (through the availability of federal funding) to shift state and local policing to a homeland security model, this had largely not occurred (the main exception being in New York City, with a very large police service and a direct experience of terrorism). Instead, the evidence suggested that mainstream policing has continued with remarkable resistance, to avoid a homeland security model, and maintain its focus in most agencies on community and professional models of policing.

This requires some understanding of how non-specialised police units (that is, not specific security or anti-terrorism squads) can be assessed as being involved in counter-terror policing. Innes (2006) sees two dimensions to the task, prospective (surveillance and target hardening) and reactive (responding and reassuring). Clarke and Newman (2007) suggest it to be really an extension of mainstream policing, involving the collection of intelligence, identification and protection of vulnerable targets, and first response to actual attacks. Bayley and Weisburd (forthcoming) list similar factors - strategic planning, risk alert, first response and collaboration. Both authorities point to the advantages possessed by local police in approaching these tasks, in that in their day to day duties they have more opportunities for routine observations then do non-local specialised units, they have access to local sources of information, their analysis of mainstream crime patterns may reveal activities that are precursors to terrorist attacks (eg thefts of bomb-making chemicals) and they are best placed to develop partnerships with other local agents of social observation and control. There is also a degree of agreement on the main disadvantages of mainstream police involvement in counter-terrorism (Bayley and Weisburd, forthcoming). It creates an enormous new pressure in competition with routine crime threats for police attention and resources. Counter-terrorism activities are likely to have a deeper impact on the human rights of suspects, and to lead to complaints against and suspicion of any police agencies involved. And as a consequence, 
police relationships with their communities, carefully nurtured during the community problem-solving era of policing, are likely to be adversely affected. In fact, the very advantage held by mainstream police in counter-terrorism, their cooperative relationships with various communities, is likely to be at risk from hostility derived from aggressive security approaches (Brown, 2007).

These disadvantages and problems in devolving counter-terrorism functions down to local police suggest the need for a new model, to deal both with the problem of terrorism and also the other emerging threats discussed earlier. There has been advocacy for community policing to be expanded and integrated into counter-terrorism policing (Innes, 2006). Its advocates suggest it to be a less damaging response to civil society than a covert security model, with the advantage of being able to leverage large numbers of local police into the security effort. Kelling and Bratton (2006) argue that the necessary factors to achieve this can be adapted from broken windows policing, including training local police on indicators of terrorism, building a hostile local environment for terrorists, attacking minor offences that support terrorism and using intelligence collection to support these strategies.

Others have argued for intelligence-led policing as an organising principle for counterterrorism (McGarrell, Freilich \& Chermack, 2007; Ratcliffe, 2008; Sheptycki, 2004). They suggest that intelligence-led policing can provide an over-arching structure incorporating community and problem-oriented policing to deal with new threats. The main problem with this approach is that while police tend to be good at data collection and analysis, they may lack the capacity to 'join the dots' (Clarke and Newman, 2007) to understand the big picture. Traditionally, intelligence collection has been biased towards recurring offenders and reliant on professional informants, and there is little evidence to suggest that either of these have any particular relevance to the new types of threats. Also, old boundaries between intelligence gathered by security services and evidence gathered by police are being blurred, leading to major problems in courts accepting evidence seen as 'tainted' by intelligence gathering methods.

So, if homeland security models of policing, merging high and low functions, have not developed in a widespread manner, and community and intelligence-led approaches are both problematic, how can contemporary policing best be conceptualised so as to develop the most appropriate strategies for the new security challenges? 
The new and emerging era of policing has featured a 'pluralisation' of crime control. This refers to the rise in private police, and state and non-state entities that provide police-relevant services (Crawford, Lister, Blackburn \& Burnett, 2005; Mazerolle \& Ransley, 2005, 2006). Crawford et al. (2005) employ the term 'plural policing' opposed to other terms such as 'public-private policing'. This terminology captures the diversity of entities that provide police-relevant services and it does not imply either the relationship between or the superiority of one group over another. Furthermore, it recognises that private police sometimes operate in public spaces and conversely, public police may be employed in addition to their public police role to enact services in private spaces (Crawford et al., 2005). Bayley (2006) refers to this trend in policing as a sideways shift in the roles and responsibilities of police. This sideways shift comes in many forms (Bayley, 1999; Prenzler, 2006; Sarre, 2005). Commercial entities now employ security forces or alternatively, security personnel for protection of premises, property, customers and/or employees. Furthermore, residential communities are now increasingly employing their own security. So-called, 'gated communities' employ security services to regulate access and provide protection to residents (Bayley, 1999; Sarre \& Prenzler, 2000). Internationally, large parts of military security are now provided by private corporations, even in conflict zones, while armed forces are increasingly involved in domestic policing, particularly of large scale sporting or political events (Avant, 2004; Warren, 2002). The approach has also been characterised as 'network' policing, with policing functions performed by networks of state and non-state actors (Mazerolle and Ransley, 2005, 2006; Ericson, 2007), or as the 'nodal' governance of security (Shearing, 2006) with security problems dealt with by nodes of public and private actors. These networks include public and private police, other state and regulatory agencies (such as tax, building, environmental and welfare organisations and schools) and private interests (such as landlords, realtors, banks, bar-owners and parents).

The trend to security networks has also been seen in counter-terrorism (Dupont, 2004, 2006), developed around state and non-state agencies including public and private security and policing bodies, transnational non-government organisations, and illegal organisations (Gill, 2006). While there has been a rise in these security networks, they have been largely unmapped and shrouded in secrecy (Dupont, 2004, 2006), with a tendency for them to have a conflation of legal, executive and judicial powers (Brodeur, 2007). The big shift has been to the hybridisation of the high policing or security function, with an increasingly prominent but 
still largely unacknowledged role for private interests (eg private security companies operating to support United States forces in occupied territories). Responding to terrorism has been responsibilsed (Palmer and Whelan, 2006) both on a macro level so that the general public has been educated to be alert to risks, and a micro level, where the owners of specific types of infrastructure (financial institutions, chemical factories) have specific new duties of observation and surveillance.

Not all attempts at networked policing succeed, with Crawford (2006a) arguing that the British experiment with legislatively mandated community safety partnerships has largely failed. He argues that in fact there has been a return to public policing, not as a monopoly, but with the state existing as an 'anchor' in the policing function around which different levels of private and public functions are organised. Both public and private security have been marketised, so that the state both buys in private services, but also trades in the provision of public safety. As a result, both private and public security are now harnessed to achieving public goals, such as the use of exclusion and dispersal orders on public and private property. The real difference then between public and private security in the new environment is the symbolic place and power of public police, but even here public law norms are being extended to private police, as non-compliance with them becomes increasingly criminalised.

Against this background, the key question is how states can best deploy both state and nonstate forms of coercion and control to respond to terrorism and other uncertain threats (Crawford, 2006a). This involves two other sub-questions, first how new accountability structures can also be developed that hold states and their public and private agents responsible for their actions and coercive force, when clearly old-style vertical lines of reporting are no longer adequate. Second, in dealing with terrorism and other intractable or ‘dirty’ issue of government (Doig, 2006), how can a ‘joined up’ response be achieved across loose and unmapped security networks? That is, how can existing coordination mechanisms, which tend to have internal tensions and be poorly achieved, be improved?

The notion of "third party policing” (Mazerolle and Ransley, 2005, 2006) has emerged as a way of understanding how public police can steer these crime control networks, by mobilising other parties and making use of their resources. Third party policing occurs when police engage with other organisations or individuals and use a range of civil, regulatory and administrative laws to create or enhance crime control and prevention networks. The focus 
shifts from sole police responsibility for preventing and responding to criminal and anti-social behaviour to networks using a wide range of legal options, but with the police at the centre of the networks, rather than as simply another node. Such networks can focus on risk identification, surveillance and prevention, rather than on traditional, reactive police strategies, and make use of a wide range of non-traditional legal powers and levers. Some of the legal measures used include property forfeiture, licence restrictions, evictions and injunctions. The distinctive feature of this type of policing is that use is made of legal mechanisms outside the criminal law (eg civil forfeiture, eviction, nuisance injunctions, liquor licensing, anti-social behaviour and truancy orders, private contract and tort laws). Police therefore gain access to new levers that in most cases are less hindered by restrictions and protections developed around criminal law processes. In addition, they gain crime control partners who are convinced or coerced to take responsibility for local problems. In third party policing, the police create or enhance crime control guardians in places and situations where guardianship was previously either ineffective or absent (Mazerolle \& Ransley, 2005). Police work in partnership with other institutions, agencies and individuals in an effort to prevent and more effectively deal with crime problems. But unlike other types of police-community networks, third party policing is characterized by top-down strategies that compel the police to harness new, coercive powers from other network nodes, to help improve crime control. We expand this synopsis of third party policing in the last section of our paper.

\section{Earlier models of policing}

Weisburd and Braga (2006) describe police at the turn of the twentieth century as emerging from three decades of change and innovation. Policing had evolved from a politically controlled and directed form of social control, through a reform or professional model focused on reactive crime control, to new forms of community and problem-oriented policing, the three dominant policing eras identified by Kelling and Moore (1988). Kelling \& Moore’s (1988) analysis of these three eras focused on factors including legitimacy, function, organisational design, external relationships, demand management, principal programs and technologies and measured outcomes (see first three columns of Table 1). While this analysis is focused on North American policing, much of it is relevant to countries such as Australia and Britain, although with some variations.

Innovations in the 1980s and 1990s arose from frustrations with the professional model and its main strategies (see Weisburd \& Braga, 2006). The community problem-solving era that 
emerged in the 1980s depended for legitimacy on both the rule of law and the support of the community. Police functions still centred on crime control, but with a new emphasis on crime prevention and order maintenance. Organisations promoted a decentralised approach to decision-making, community consultation and demand management, with local area input actively sought. Strategies expanded to include a focus on problem-solving, with performance indicated by problem solution, reduction of fear of crime and quality of life as well as tallies of police activity (Moore and Braga, 2003). Critics of the community era, however, lament that the problem-solving and community focus was illusory rather than real, with 'businessas-usual' the reality (Mastrofski, 2006). Others saw the police difficulties in defining and engaging with their communities as another shortcoming of the community policing era.

By the start of the twenty-first century, a great deal of experimentation and innovation in police work was occurring, as documented by Weisburd and Braga (2006). They identify four interrelated categories of innovation, including technological (eg DNA analysis, computerised crime mapping and analysis and electronic surveillance), programmatic (using existing operational resources in new ways, eg in drug education programs in schools), administrative (organisational changes to focus in the conduct or assessment of operations eg new performance indicators) and strategic innovation (fundamental shifts in direction eg pluralisation of policing, 'broken windows' policing). Since 9/11, this fertile field of innovation began to change again. As Weisburd and Braga (2006) note, a new era in policing is emerging primarily because the pressures for change have themselves been altered. Crime rates are decreasing and the new policing imperatives are concentrated on security. These pressures reverberate in legislative activity and in government funding. As we have suggested above, the main new imperative is the uncertainty of new challenges, but one of its side effects has been to marginalise or subjugate the traditional police role to that of other agencies.

\section{A new policing model for a new era?}

We have argued that with the $21^{\text {st }}$ century a new environment emerged for modern democratic states, heralding not just the escalation of mass terrorism, but of a range of other unknown and often unknowable threats. These threats share some common features, mainly the uncertainty around their nature and likely impact, equal uncertainty about suitable responses to prevent or manage them, their transnational impact, and the way in which they have encouraged a convergence of various state and non-state agencies to develop new responses. We suggest 
that these events, coupled with fundamental changes already affecting policing models, have shifted contemporary policing into a new era, the era of uncertainty. We describe this new era using the same categories of corporate strategy analysis applied by Kelling and Moore (1988) to earlier policing eras (political, reform and community problem-solving). Our analysis is summarised in the final column of Table 1. We aim to explain, to some degree, the impetus for the shift and to highlight how policing strategies and tactics can be adapted to suit the demands of a new environment, but also how police can regain their centrality to the policing function.

Based on Kelling and Moore's (1988) model, we propose that policing has now shifted into a new era of uncertainty, encapsulated in the last column of Table 1. This era combines the tensions and changing boundaries between high and low policing, with the trend to policing and security networks and third parties. Its main features are set out below.

Legitimacy and authorisation: In this new era of uncertainty, legitimacy and authorisation derive from a much wider variety of legal sources (criminal law, international law, torts, regulatory and administrative law etc) than was apparent in the community policing era of policing (see Mazerolle and Ransley, 2005, 2006). However, community and third party partners still play an equally important role in establishing the legitimacy of police interventions. Police need community authorisation for their extended and empowered functions and must maintain the cooperation and indeed, in some cases, endorsement of their local communities to form partnerships and networks, and exercise their expanded coercive powers. Any failure to secure community authorisation for police work risks the potential alienation of sectors of that community. In Australia, a potent example of this alienation is evident in the case of Dr Mohamed Haneef. Dr Haneef, an Indian national, and Muslim, was arrested on 2 July 2007, detained under terrorism powers for 12 days, then charged with terrorism offences which later collapsed, at which point his visa was cancelled and he was transferred to immigration detention where he was held for another 15 days, before eventually being released and allowed to fly home (Lynch, 2007). The apparently bungled police investigation, the weakness of the case against Haneef, the alleged cooption and misuse of immigration powers, and the targeting of an Islamic man, led to an enormous wave of criticism of the AFP, and then to a deeper critique of its role, functions and powers, and eventually to a highly embarrassing public inquiry into the conduct of the investigation 
(Australia, 2008). Maintaining continuing community support for police is an essential task, yet an increasingly challenging one.

The police function: Crime control remains a key function of police in the era of uncertainty, yet added to the crime control role of police are potentially competing responsibilities around control of security threats and the myriad of commitments to the increasingly complex network of regulatory and social policy responsibilities. This is part of the pay-off for police gaining access to regulatory powers and levers possessed by other agents, that in return, their own policing needs to recognise and accommodate the broader goals. The function of Australian police, for example, has rapidly broadened to include not only security and counter-terrorism, but also overseas deployments in regional peacekeeping and joint security taskforces. Up to 500 police are serving abroad at any time, representing nearly 10 per cent of total AFP staff (McFarlane, 2007). In addition, the intervention in Indigenous communities in the Northern Territory has drawn more resources (Howard-Wagner, 2007), both expanding the police role and function, and diluting available resources to actually do the necessary work.

Organizational design: One of the features of the era of uncertainty is the rolling back of some community-era reforms. Centralized police squads, disbanded in favour of decentralized and matrix based teams of specialists coming together for special investigations, have been reestablished as specialist teams (e.g. counter-terrorism units, child protection teams) and the complex matrix of officers working in seconded policing roles (e.g. peace-keeping) and in close proximity with officers from other law enforcement agencies (e.g. US Fusion Centers). Thus, organisational design has become less clear, as acknowledged by Bayley and Weisburd (forthcoming) discussed above, with responsibilities organised in a variety of different functional ways mainly depending on local political structures and history. The main features are the existence of hybridisation of high and low policing, and co-existence of public and private interests, anchored around the legitimacy of the public police.

External relationships: As with the community policing era, policing in the era of uncertainty is reliant on an effective working relationship between the police and the community, and this ties closely with the continuing need for community authorisation and legitimacy discussed above. Nonetheless, much of the work of police in the new regulatory environment (see Mazerolle and Ransley, 2006) leads the police to use somewhat coercive methods to elicit 
compliance. For example, the use of civil remedies can, in some situations, be used in a coercive fashion to bring about a crime control benefit. The relationship between the police organisation and its environment has shifted from the purely consultative model promoted in the community era, to one that also exercises a considerable degree of coercive force, over third party partners to induce their cooperation in crime and security control efforts.

Demand management: Unlike in the community policing era, in the era of uncertainty many of the demands placed on police derive from external agencies that co-opt the police for a wide range, and increased range, of crime control matters. For example, Taxation Departments and Departments of Child Safety work closely with police on matters within their jurisdiction, yet now place additional demands on police that may have, in the past, have come from within the organisation. Additional demands might include reporting on case files to non-police boards and attending hearings to external oversight commissions that might have been heard internally in the past. These are, of course, reciprocal relationships where the police also co-opt the resources of these new regulatory agencies, creating a much more complex web of law enforcement than what has been the case in past eras of policing. Demand may also be in the form of government imperatives (eg homeland security measures, crime reduction partnerships or social policy programs) or may derive from the need for sudden and immediate response to new and unheralded threats, such as large-scale terrorist attacks.

Principal programs and technologies: Although the community era saw the rise of technologies to help shape police responses, the rapid expansion of technologies have fundamentally changed the face of policing. In the $21^{\text {st }}$ century, the era of uncertainty is most characterised by its heavy investment in a range of new, innovative technologies, most notably information (crime mapping, data mining, storage and retrieval systems) and surveillance (CCTV, listening devices, satellite) technologies. These technologies are used in a range of information dependent tactics such as problem-oriented policing and intelligence led policing. Technology is a primary tool, both for information gathering (intelligence systems, surveillance) and for analysis (COMPSTAT, risk assessment tools).

Measured outcomes: Outcomes of success within the era of uncertainty tend to be measured by crime and terrorism control, a reverting back, in some ways, to the outcomes that were important in the reform era of policing. But as well as the extent to which crime and security 
threats are controlled and prevented, the extent to which fear and disruption in the community are minimised are also important outcomes. Further, as discussed above, the maintenance of democratic standards of policing is in itself a desirable outcome, to ensure that responses are proportionate and in keeping with the rule of law. There is much debate as to the balancing of the rule of law with the need for police to protect citizenry from terrorist attack. This balancing exercise is often presented as one where rights and the rule of law need to give way to the urgent need for protection from unknown emergent threats. But democratic policing that respects rights and the rule of law can alternatively be seen as promoting security, by enhancing legitimacy and community cooperation, which in turn assists in turning unknowable risks into more manageable challenges.

\section{Conclusion}

We have argued that the beginning of the $21^{\text {st }}$ century has coincided with a changing crime and security environment, and the development of new and unanticipated problems and threats. These problems include external security threats, such as terrorism, mass movements of people and the accompanying threat of disease and dislocation, failing states and those experiencing prolonged political unrest or poverty, and potentially, problems caused by climate change. New internal security threats include the need to maintain social inclusion in a rapidly changing society, by addressing entrenched social problems and behaviours. In Australia, these threats have resulted in policing and security powers and responsibilities being extended to a broad range of police, security, regulatory, administrative and private agents who form loose networks with overlapping functions. These networks have been shown to suffer from lack of coordination, focus and central leadership, with the police often at the margins or at best sharing a coordinating role with other players.

Uncertainty provides at least part of the impetus for changes to policing that have occurred. The emergence of new and unforseen security threats has led to a breaking down of boundaries between police, military and security boundaries, at the same time as pluralised or nodal policing was developing to confront mainstream crime problems. Models of police activity had changed in the 1980s and 1990s, so that earlier political and professional models were being at least partly displaced by community and problem-solving policing. But these approaches generally suffered from poor take-up and success, and a failure to respond sufficiently rapidly and flexibly to deal with the new era of uncertainty. In an uncertain age, the scope or even existence of problems may be unclear or unknown, and new ways of 
identifying and assessing risk are required. This applies not just to the crime problems that police face, but increasingly to their role and influence in crime control networks.

We suggest that in an era of uncertainty a new model of police activity is necessary for public police to maintain their leadership role in the provision of security and crime control, and we have sketched out the dimensions of a model based on the idea of third party policing, using the elements established by Kelling and Moore (1988). It remains to be seen whether police agencies seize this opportunity, and this will provide fertile grounds for future empirical and theoretical research. 
Table 1. Comparative summary of models of policing

\begin{tabular}{|c|c|c|c|c|}
\hline \multirow{2}{*}{$\begin{array}{l}\text { Corporate Strategy } \\
\text { Categories }\end{array}$} & \multicolumn{4}{|c|}{ Characteristics of the Era } \\
\hline & Political Era & Reform Era & Community Problem-Solving Era & Uncertainty Era \\
\hline Authorisation & Political & Rule of law and professionalism & Community, law and professionalism & $\begin{array}{l}\text { Law (criminal, international, } \\
\text { regulatory and administrative), } \\
\text { community, and regulatory partners }\end{array}$ \\
\hline Function & $\begin{array}{l}\text { Crime control, order maintenance and } \\
\text { social services }\end{array}$ & Crime control & $\begin{array}{l}\text { Crime control, crime prevention and } \\
\text { problem-solving }\end{array}$ & $\begin{array}{l}\text { Crime, security and terrorism control, } \\
\text { crime prevention, regulation, social } \\
\text { policy }\end{array}$ \\
\hline Organisational Design & Decentralised and geographical base & Centralised & $\begin{array}{l}\text { Decentralised and use of Specialist } \\
\text { Taskforces }\end{array}$ & $\begin{array}{l}\text { Centralised specialist teams and } \\
\text { fusion centres (seconded officers from } \\
\text { a variety of enforcement and } \\
\text { intelligence agencies) }\end{array}$ \\
\hline External Relationships & Intimate & Professional & Consultative & Consultative and Coercive \\
\hline Demand & $\begin{array}{l}\text { Linkages between politicians and } \\
\text { local police leaders and direct } \\
\text { interaction between the community } \\
\text { and police }\end{array}$ & Central despatch & $\begin{array}{l}\text { Based on analysis of underlying crime } \\
\text { and disorder problems }\end{array}$ & $\begin{array}{l}\text { Based on analysis of underlying } \\
\text { problems and from demands placed } \\
\text { on police from external agencies }\end{array}$ \\
\hline Tactics and Technology & Foot patrol & $\begin{array}{l}\text { Preventative patrol and rapid response } \\
\text { to calls for service }\end{array}$ & Foot patrol and problem-solving & $\begin{array}{l}\text { Information technologies (e.g crime } \\
\text { mapping), new surveillance } \\
\text { technologies, and new approaches } \\
\text { (e.g. Intelligence-led policing, } \\
\text { COMPSTAT) that are reliant on } \\
\text { information technologies }\end{array}$ \\
\hline Outcome & Political and community satisfaction & Crime control & $\begin{array}{l}\text { Community satisfaction and Quality } \\
\text { of Life indicators }\end{array}$ & $\begin{array}{l}\text { Crime, security and terrorism control } \\
\text { Compliance with rule of law }\end{array}$ \\
\hline
\end{tabular}

Source: Adapted from Kelling \& Moore (1988) 


\section{References}

Australia (2005). National Counter-Terrorism Plan. Canberra: Attorney-General's Department. Retrieved 10 November 2007 from www.ag.gov.au/agd/www/nationalsecurity.nsf/AllDocs/85A16ADB86A23AD1CA256FC600 072E6B?OpenDocument।

Australia (2008). Clarke Inquiry into the case of Dr Mohamed Haneef. Canberra: AttorneyGeneral's Department. Retrieved May 2008 from http://www.haneefcaseinquiry.gov.au/www/inquiry/haneefcaseinquiry.nsf/Page/Home

Avant, D. (2004). The privatization of security and change in the control of force. International Studies Perspectives, 5, 153-157.

Baldino, D. (2007, September). Good instincts or poor judgement? Australia's counterterrorism response after 9-11. Paper presented at Australian Political Studies Association Conference, Monash University, Melbourne, Australia.

Bammer, G. (2007). Key concepts underpinning research integration. Integration Insights, No. 5, May. Retrieved 10 November 2007 from www.anu.edu.au/iisn.

Bammer, G. and Smithson, M. (Eds.). (2008). Uncertainty and Risk: Multidisciplinary Perspectives. London: Earthscan.

Bammer, G., Smithson, M. \& and the Goolabri Group. (2008). The Nature of Uncertainty. In G. Bammer \& M. Smithson (Eds.). Uncertainty and Risk: Multidisciplinary Perspectives. London: Earthscan.

Bayley, D. (1999). Capacity-building in law-enforcement. Trends and Issues in Crime and Criminal Justice, No. 123. Canberra: Australian Institute of Criminology.

Bayley, D. (2005). Police reform as foreign policy. Australian and New Zealand Journal of Criminology, 38(2), 206-215.

Bayley, D. (2006) Changing the guard: Developing democratic police abroad. Oxford: Oxford University Press.

Bayley, D. \& Shearing, C. (1996). The future of policing. Law and Society Review, 30(3), 585-606.

Bayley, D. \& Shearing, C. (2001). The new structure of policing: description, conceptualisation and research agenda. National Institute of Justice, Washington, DC.

Bayley, D. \& Weisburd, D. (forthcoming). The role of the police in counter-terrorism. In Weisburd, D., Mock, L., Hakimi, I., Feucht, T. \& Perry, S. To Protect and To Serve: Policing in an age of terrorism. New York: Springer Verlaag.

Beck, U. (2002). The terrorist threat: world risk society revisited. Theory, Culture and Society, 19(4), 39-55. 
Bergin, A., Azarias, J. \& Williams, D. (2008). Advancing Australian homeland security: Leveraging the private sector. Canberra: Australian Strategic Policy Institute.

Bowtell, B. (2007). Applying the paradox of prevention: Eradicate HIV. Griffith Review, 17. Retrieved March 2008 from http://www3.griffith.edu.au/01/griffithreview/past_editions.php?id=482

Brodeur, J.P. (2007). High and low policing in post-9/11 times. Policing, 1(1), 25-37.

Brown, B. (2007). Community policing in post-September 11 America: a comment on the concept of community-oriented counterterrorism. Police Practice and Research, 8(3), 239251.

Clarke, R.V. \& and Newman, G.R. (2007). Police and the prevention of terrorism. Policing, 1(1), 9-20.

Crawford, A. (2006a). Networked governance and the post-regulatory state? Steering, rowing and anchoring the provision of policing and security. Theoretical Criminology, 10(4), 449479.

Crawford, A. (2006b). Policing and security as 'club goods': the new enclosures? In J. Wood \& B. Dupont. (Eds) Democracy, Security and the Governance of Society (pp111-138). Cambridge: Cambridge University Press.

Crawford, A., Lister, S., Blackburn, S. \& Burnett, J. (2005). Plural Policing: the mixed economy of visible patrols in England and Wales. Bristol: Policy Press.

Crock, M., Saul, B. \& Dastyari, A. (2006). Future Seekers II: Refugees and irregular migration in Australia. Sydney: Federation Press.

Dequech, D. (2004). Uncertainty: individuals, institutions and technology. Cambridge Journal of Economics, 28, 365-378.

Dershowitz, A. (2005). Preemption: A knife that cuts both ways. New York: Norton.

Doig, A. (2006). Joining up a response to terrorism?... And agency shall speak to agency. Crime, Law and Social Change, 44, 423-440.

Dupont, B. (2004). Security in the age of networks. Policing and Society, 14(1), 76-91.

Dupont, B. (2006). Delivering security through networks: surveying the relational landscape of security managers in an urban setting. Crime, Law and Social Change, 45, 165-184.

Ericson, R, (2007). Rules in policing: five perspectives. Theoretical Criminology, 11(3), 367401.

Gill, P. (2006). Not just joining the dots but crossing the borders and bridging the voids: constructing security networks after 11 September 2001. Policing and Society, 16(1), 27-49. 
Goldsmith, A. (2008). The governance of terror: Precautionary logic and counterterrorist law reform after September 11. Law \& Policy, 30(2), 141-167.

Gouldby, B. \& Samuels, P, (2005). Language of risk: project definitions. Integrated Flood Risk Analysis and Management Methodologies Report. Retrieved 10 November 2007 from www.floodsite.net.

Howard-Wagner, D. (2007). Restoring social order through tackling 'passive welfare': the statutory intent of the Northern Territory National Emergency Response Act 2007 (Cth) and Social Security and other Legislation Amendment (Welfare Payment Reform) Act 2007 (Cth). Current Issues in Criminal Justice, 19(2), 243-251.

Innes, M. (2006). Policing uncertainty: countering terror through community intelligence and democratic policing. Annals of the American Academy, 605, 222-241.

Jiao, A.Y. \& Rhea, H.M. (2007). Integration of police in the United States: changes and development after 9/11. Policing and Society, 17(4), 388-408.

Karstedt, S. \& La Free, G. (2006). Democracy, crime and justice. Annals of the American Academy, 605, 6-23.

Kelling, G.L. \& Bratton, W.J. (2006). Policing Terrorism. Civic Bulletin, Centre for Civic Innovation, Manhattan Institute, 43, September.

Kelling, G.L. \& Moore, M.H. (1988). The evolving strategy of policing. Perspectives on Policing, No.4. National Institute of Justice, U.S. Department of Justice and the Program in Criminal Justice Policy and Management, John F. Kennedy School of Government, Harvard University.

Kennison, P. \& Loumansky, A. (2007). Shoot to kill - understanding police use of force in combating suicide terrorism. Crime, Law and Social Change, 47, 151-168.

Loader, I. (2006). Fall of the platonic guardians: liberalism, criminology and political responses to crime in England and Wales. British Journal of Criminology, 46, 561-586.

Loader, I. \& Walker, N. (2006). Necessary virtues: the legitimate place of the state in the production of security. In J. Wood \& B. Dupont (Eds) Democracy, Security and the Governance of Society (pp165-195). Cambridge: Cambridge University Press.

Lynch, A. (2007). Security, rights and the rule of law. In A. Lynch, E. Macdonald \& G. Williams (eds) Law and liberty in the war on terror (pp222-233). Sydney: Federation Press.

Manning, P.K. (2005). The study of policing. Police Quarterly, 8(1), 23-43.

Manning, P.K. (2006). Two case studies of American anti-terrorism. In J. Wood \& B. Dupont (Eds) Democracy, Security and the Governance of Society (pp52-85). Cambridge: Cambridge University Press.

Mastrofski, S.D. (2006). Community Policing: a sceptical view. In D. Weisburd \& A.A. Braga (Eds) Police Innovation: contrasting perspectives. Cambridge: Cambridge University Press. 
Mazerolle, L. \& Ransley J. (2005). Third Party Policing. Cambridge: Cambridge University Press.

Mazerolle, L. \& Ransley, J. (2006). Third party Policing. In D. Weisburd \& A.A. Braga (Eds) Police Innovation: contrasting perspectives. Cambridge: Cambridge University Press.

McFadden, M., Lyon, R. \& and Pinsker, R. (2008), Uncertainty, terrorism and law enforcement. In Bammer, G. and Smithson, M. (Eds.) Uncertainty and Risk:

Multidisciplinary Perspectives. London: Earthscan.

McFarlane, J. (2007). The thin blue line: The strategic role of the Australian Federal Police. Security Challenges, 3(3), 91-108.

McGarrell, E.F., Freilich, J.D. \& Chermak, S. (2007). Intelligence-led policing as a framework for responding to terrorism. Journal of Contemporary Criminal Justice, 23(2), 142-158.

Moore, M. \& Braga, A. (2003). Measuring and improving police performance: the lessons of COMPSTAT and its progeny. Policing: an International Journal of Policing Strategies and Management, 26(3), pp439-453.

Mythen, G. (2005). From 'goods' to 'bads'? Revisiting the political economy of risk. Sociological Research Online, 10(3). Retrieved 10 November 2007 from www.socresonline.org.uk/10/3/mythen.html

Mythen, G. and Walklate, S. (2006). Criminology and terrorism: which thesis? Risk society or governmentality? British Journal of Criminology, 46, 379-398.

Nicholls, G. (2007). Deported: a history of forced departures from Australia. Sydney: UNSW Press.

Norton, J.P., Brown, J.D. \& Mysiak, J. (2006). To what extent, and how, might uncertainty be defined? Integrated Assessment Journal, 6(1), 83-88.

O’Reilly, C. \& Ellison, G. (2006). Eye spy private high: re-conceptualising high policing theory. British Journal of Criminology, 46, 641-660.

Ortiz, C.W., Hendricks, N.J. \& Sugie, N.F. (2007). Policing Terrorism: The response of local police agencies to homeland security concerns. Criminal Justice Studies, 20(2), 91-109.

Palmer, M. (2005). Inquiry into the immigration detention of Cornelia Rau. Canberra: Department of Immigration. Retrieved March 2008 from http://www.immi.gov.au/media/publications/pdf/palmer-report.pdf

Palmer, D. \& Whelan, C. (2006). Counter-terrorism across the policing continuum. Police Practice and Research, 7(5), 449-465.

Prenzler, T. (2006). The privatisation of policing. In R. Sarre \& J. Tornaino (Eds.). Key Issues in Criminal Justice. Adelaide: Australian Humanities Press. 
Ratcliffe, J.H. (2008). Intelligence-Led Policing. Cullompton, Devon: Willan Publishing.

Sarre, R. (2005). Researching private policing: Challenges and agendas for researchers. Security Journal, 18(3), 57-70.

Sarre, R. \& Prenzler, T. (2000). The relationship between police and private security: models and future directions. International Journal of Comparative and Applied Criminal Justice, 24(1), 91-113.

Shearing, C. (2006). Reflections on the refusal to acknowledge private governments. In J. Wood \& B. Dupont (Eds) Democracy, Security and the Governance of Society (pp11-32). Cambridge: Cambridge University Press.

Sheptycki, J. (2004). Review of the influence of strategic intelligence on organised crime policy and practice. London: Home Office Research and Statistics Directorate.

Skolnick, J.H. (2005). Democratic policing confronts terror and protest. Syracuse Journal of International Law \& Commerce, 33(19), 191-212.

Smithson, M. (2008). The many faces and masks of uncertainty. In Bammer, G. and Smithson, M. (Eds.) Uncertainty and Risk: Multidisciplinary Perspectives, (pp. 13-26). London: Earthscan.

Smithson, M. (1993). Ignorance and science: Dilemmas, perspectives and prospects. Science Communication, 15, 133-156.

Spelman, W. \& Brown, D.K. (1984). Calling the police: citizen reporting of serious crime. Washington: National Institute of Justice.

Stern, J. \& Wiener, J. (2006). Precaution against terrorism. Journal of Risk Research, 9(4), 393-447.

Street, L. (2008). A review of interoperability between the AFP and its national security partners. Canberra: Australian Federal Police. Retrieved March 2008 from www.afp.gov.au/_data/assets/pdf_file/71833/The_Street_Review.pdf

Warren, R. (2002). Situating the city and September 11th: Military urban doctrine, 'pop-up' armies and spatial chess. International Journal of Urban and Regional Research, 26.3, 614619.

Weisburd, D. and Braga, A.A. (2006). Conclusion: police innovation and the future of policing. In Weisburd, D. and Braga, A.A. (Eds) Police Innovation: contrasting perspectives, (pp339-350). Cambridge: Cambridge University Press.

Weisburd, D. \& Eck, J.E. (2004). What can police do to reduce crime, disorder and fear? The Annals of the American Academy, 593, pp42-65.

Wood, J. (2006). Research and Innovation in the field of security: a nodal governance view. In J. Wood \& B. Dupont (Eds) Democracy, Security and the Governance of Society (pp217240). Cambridge: Cambridge University Press. 